\title{
A Non-Viral Vector for Targeting Gene Therapy to Motoneurons in the CNS
}

\author{
Francisco J. Miana-Mena ${ }^{a}$ María J. Muñoz $^{b}$ Sylvie Roux $^{c}$ Jesús Ciriza $^{a}$ \\ Pilar Zaragoza ${ }^{a}$ Philippe Brûlet $^{c}$ Rosario Osta ${ }^{a}$ \\ aLaboratorio de Genética Bioquímica y Grupos Sanguíneos, Facultad de Veterinaria de Zaragoza, y \\ bDepartamento de Farmacología y Fisiología, Facultad de Veterinaria de Zaragoza, Zaragoza, España; \\ 'Unité d'Embryologie Moléculaire, Institut Pasteur, Paris, France
}

\section{Key Words}

Gene therapy · Naked DNA · Tetanus toxin,

C fragment $\cdot$ Pattern expression $\cdot$ Retrograde transport .

Transsynaptic transport

\begin{abstract}
Gene therapy vectors that can be targeted to motoneuronal cells are required in the field of neurodegenerative diseases. We propose the use of the atoxic fragment $C$ of tetanus toxin (TTC) as biological activity carrier to the motoneurons. Naked DNA encoding $\beta$-galactosidaseTTC hybrid protein was used to transfect muscle cells in vivo, resulting in a selective gene transfer of the enzymatic activity to the CNS. In the muscle, level expression of $\beta$-galactosidase was readily detectable $24 \mathrm{~h}$ after injection, reaching a maximum after 4 days and gradually decreasing thereafter. Labelling in the hypoglossal motoneurons and motor cortex was observed from 4 days after injection. In this paper, we show that TTC works as an enzymatic activity carrier to the CNS when muscle cells are transfected in vivo. We have also shown that the presence of TTC does not have any influence on the expression of the transfected gene. Both these results warrant further studies of TTC as a means of treating motoneuron diseases in the field of gene therapy.
\end{abstract}

Copyright @ 2004 S. Karger AG, Basel

\section{Introduction}

Motoneuron diseases such as spinal muscular atrophy and amyotrophic lateral sclerosis are characterized by varying degrees of motoneuron degeneration. This results in progressive muscular atrophy and paralysis, leading invariably to death in amyotrophic lateral sclerosis and in most forms of spinal muscular atrophy. Various proteins such as neurotrophic factors, anti-apoptotic agents or anti-oxidants have been identified as potential therapeutic agents. Thus, neurotrophic factors (GDNF, BDNF, NT3, etc.) used in vitro have been shown to improve the motoneuron survival [1]. In clinical trials, the neurotrophins act on neurons affected by other neurological and psychiatric pathologies [2]. Gene transfer has been explored in vivo to deliver the enzymatic activities to the brain using adenoviral, lentiviral or adeno-associated viral vectors, which are efficient in transducing cells [3-6]. However, non-viral delivery systems are an attractive alternative due to safety concerns regarding the use of viruses in humans.

The atoxic C-terminal fragment of tetanus toxin or TTC retains the properties of the holotoxin [7]. TTC is necessary (and sufficient) for neuron binding, internalization, retrograde and transsynaptic transport $[8,9]$. Moreover, studies both in vitro and in vivo have shown that

Dr. Rosario Osta Pinzolas

Laboratorio de Genética Bioquímica y Grupos Sanguíneos

Facultad de Veterinaria de Zaragoza, C/Miguel Servet 177

ES-50013 Zaragoza (Spain)

Tel. +349767616 20, Fax +349767616 12, E-Mail osta@posta.unizar.es 
TTC has the capacity to deliver other large proteins linked by chemical or genetic fusion, such as horseradish peroxidase [10], $\beta$-galactosidase [11], superoxide dismutase [1214] and cardiotrophin 1 [15] into neurons. For this reason, TTC is considered to be a promising alternative to invasive viral gene systems for delivering biological activity to the CNS. In these studies, all fusion proteins were administered in vivo via an intramuscular injection, after their production in prokaryote vectors. An alternative to a direct protein injection would be to induce protein production within the muscle, by naked DNA administration. This method has previously been used in Xenopus [16], where retrograde transport to the neural soma of a TTC fusion protein has been demonstrated.

In this paper, we show that this method also works in mammals, where both retrograde and transsynaptic TTC transport is evident. Furthermore, expression of the reporter gene ( $\beta$-galactosidase enzyme) does not appear to be modified by the presence of the TTC protein.

These studies show the considerable potential of using the TTC to treat motoneuron diseases by gene therapy.

\section{Material and Methods}

\section{Plasmid DNA Constructions}

The different plasmid DNAs utilized in these studies contained an enhancer for the cytomegalovirus (CMV) promoter and the $\beta$ galactosidase reporter gene. $\mathrm{pCMV}-\beta$-gal-TTC and $\mathrm{pCMV}-\beta$-gal have been previously described [16]. $\beta$ pCMV-NLS- $\beta$-gal (gift of A. Chouli$\mathrm{ka}$, Institut Pasteur) contains a nuclear localization signal.

Plasmids were propagated and purified using Endofree Plasmid Maxi Kits (Qiagen) and resuspended in Tris-EDTA endotoxin-free solution.

Animals and Intramuscular Injections of Plasmid DNA

All experiments complied with European laws for the protection of experimental animals.

98 six-week-old Wistar rats and 10 six-week-old CD1 mice obtained from Iffa Credo and Charles River, respectively, were used in these studies. Animals were anaesthetized with pentobarbital $(200 \mathrm{mg} / \mathrm{kg})$. The intramuscular injection of plasmid DNA or TrisEDTA alone was performed in the tongue using an insulin syringe (Becton Dickinson). Due to the different sizes of the plasmids, a correction factor was applied to administer a similar copy number in each case. 15,15 and 18 rats were injected with low doses which corresponded to $100 \mu \mathrm{g} / 100 \mu \mathrm{l}$ for pCMV-NLS- $\beta$-gal and pCMV- $\beta$ gal plasmids and $130 \mu \mathrm{g} / 100 \mu \mathrm{l}$ for pCMV- $\beta$-gal-TTC. Otherwise 15 , 15 and 29 rats were injected, respectively, with the high dose $300 \mu \mathrm{g} / 300 \mu \mathrm{l}$ for pCMV-NLS- $\beta$-gal and pCMV- $\beta$-gal plasmid and $390 \mu \mathrm{g} / 300 \mu \mathrm{l}$ for pCMV- $\beta$-gal-TTC.

Intracardiac perfusion with PBS and $4 \%$ paraformaldehyde in PBS at $4{ }^{\circ} \mathrm{C}$ under deep anaesthesia was performed. Tongue and brain from injected animals were removed $1,4,7,15,30$ or 60 days after injection.
We found that at $\mathrm{pH} 7.6$ endogenous $\beta$-galactosidase activity was not observed so all the following experiments were performed using this working value for the $\mathrm{pH}$. Note that this $\mathrm{pH}$ value is not inconsistent with previous studies $[17,18]$, as the perfusion and detection conditions are slightly different in our case.

\section{Histological Analyses}

For in toto $\beta$-galactosidase activity detection, the $\mathrm{X}-\mathrm{Gal}$ reaction was performed as previously described [11]. At this level, endogenous $\beta$-galactosidase does not react, as described before [14-16]. For histological analyses, dissected tissues that had been incubated overnight in $15 \%$ sucrose at $4{ }^{\circ} \mathrm{C}$ were cut $(20 \mu \mathrm{m})$ with a cryostat. Sections were stained as described above and counterstained with fast nuclear red. For inmunohistology with TTC antibody, sections were processed as described [16].

\section{Electron Microscopy Analyses}

For electron microscopy, 10 six-week-old CD1 mice were used. 3, 3 and 4 animals were injected with $20 \mu \mathrm{g} / 20 \mu \mathrm{l}$ for pCMV-NLS- $\beta$-gal and pCMV- $\beta$-gal plasmids and $26 \mu \mathrm{g} / 26 \mu \mathrm{l}$ for pCMV- $\beta$-gal-TTC. The muscle removed was cut into $150-\mu \mathrm{m}$ vibratome sections and incubated in X-Gal solution. The X-Gal precipitate is electron dense and can be detected by direct examination as described [19]. X-Galpositive sections were thus treated for electron microscopy and embedded in Epon resin. Ultrathin sections were examined with a Zeiss transmission electron microscope.

\section{Statistical Analyses}

The statistical analyses of $\beta$-galactosidase transgene expression in muscle cells in 107 rats were mainly based on the three-way factorial analyses of variance (ANOVA). In order to carry out a deeper analysis of the different factors influencing plasmid expression, several Student $t$ tests with a standard statistical threshold of $5 \%$ were performed. All statistical calculations were carried out using the Statistica version 5.0 program.

\section{Results}

\section{$\beta$-gal-TTC Migration to the CNS}

As described in the following section, $\beta$-galactosidase activity in the muscle was detected after injection, regardless of the administered plasmid construction (pCMV- $\beta$ gal-TTC, pCMV- $\beta$-gal or pCMV-NLS- $\beta$-gal) or its dose. As a negative control, animals were injected with different volumes of Tris-EDTA buffer and analysed throughout the course of time. No X-Gal staining was observed in non-DNA-injected muscles, which demonstrated the specificity of labelling.

Histological studies showed that in all cases the $\beta$-galTTC protein had a uniform distribution in the cytoplasm of transfected fibres (fig. 1a-c). The first evidence that the $\beta$-gal-TTC hybrid protein was released from transfected muscular fibres was obtained by light microscopy. The XGal precipitate was detected from the first day of the time course, having a uniform distribution in the transfected 

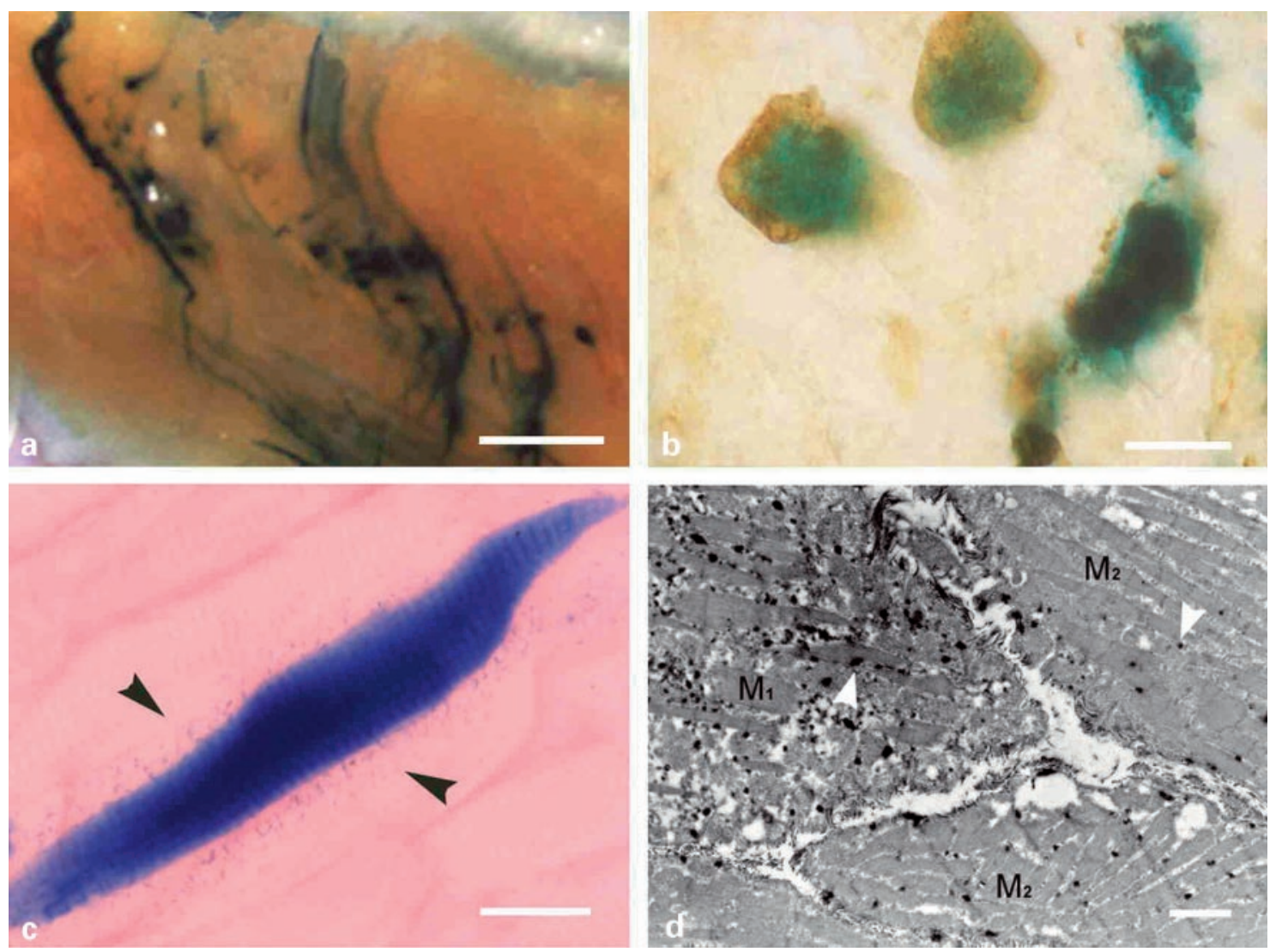

Fig. 1. Expression and interfibrillar passage of the $\beta$-gal-TTC hybrid protein after a naked DNA injection. a Muscular fibres showed $\beta$ galactosidase activity in a tongue injected with pCMV- $\beta$-gal-TTC construction 4 days after injection. Bar $=1 \mathrm{~mm}$. b Representative examples of muscle fibres in cross-sections from animals injected with the CMV- $\beta$-gal-TTC plasmid. The sections were histochemically stained for $\beta$-galactosidase expression and then immunostained for TTC (rabbit anti-TTC antibodies; dilution 1:1,000). Dark brown
TTC signal co-localization with blue-stained muscle fibres that have $\beta$-galactosidase activity demonstrates the complete expression of the $\beta$-gal-TTC hybrid protein. Bar $=10 \mu \mathrm{m}$. c X-Gal staining on muscle sections indicated that $\beta$-galactosidase activity passes from the transfected fibre to the adjacent fibres (black arrowheads). Bar $=10 \mu \mathrm{m}$. d High magnification of this passage with electron microscopy. $\mathbf{M}_{1}=$ transfected fibre; $\mathrm{M}_{2}=$ adjacent fibre. White arrowheads indicate the $\mathrm{X}$-Gal precipitate. $\mathrm{Bar}=1 \mu \mathrm{m}$. fibre and only after 4 days being found in the peripheral cytoplasm of adjacent fibres. This interfibrillar passage was clearly shown by electron microscopy (fig. 1d). On the contrary, no exit from transfected muscle cells was observed for the control construction pCMV- $\beta$-gal, which lacks the TTC fragment. Labelled axons were observed to emerge from those muscles injected with pCMV- $\beta$-galTTC, suggesting that the transfer of $\beta$-gal-TTC to the motoneuron had occurred from the expression site in the muscle (fig. 2a, b). These results indicate that the $\beta$-galTTC fusion protein has the capacity to migrate from the original fibre and enter into neighbouring fibres and axons.
Transport of the fusion protein was examined in more detail by analysing X-Gal-stained brain slices. In these studies, we concentrated on enzymatic detection, as labelling with anti- $\beta$-galactosidase or an anti-TTC antibody is less informative [14], because of the small amounts of protein delivered to the CNS. Despite the high levels of expression in the tongue, no $\beta$-galactosidase activity was detected in the brain 1 day after DNA administration. Four days after injection, weak labelling was observed bilaterally in the hypoglossal nucleus, which is directly responsible for tongue activity through the 12th nerve. The hybrid protein was located in the cytoplasm of the neuron with a perinuclear distribution (fig. $2 \mathrm{c}-\mathrm{g}$ ), as occurs when the $\beta$-gal-TTC is injected as protein. 

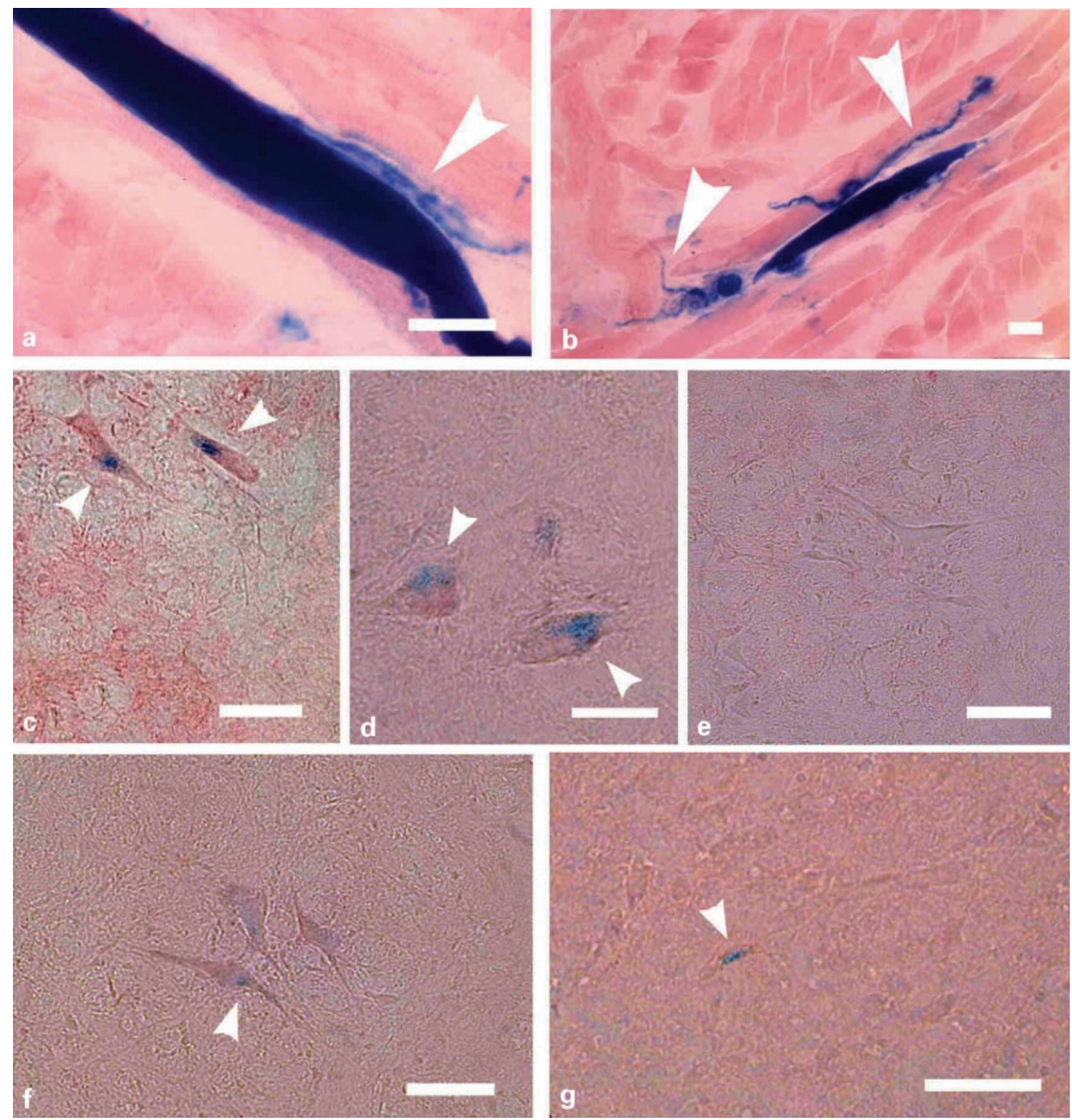

Fig. 2. Retrograde and transsynaptic transport of the $\beta$-gal-TTC hybrid protein. a, b X-Gal staining of sliced transfected muscle fibres with pCMV- $\beta$-gal-TTC shows labelling in putative motoneuron axon-like structures (white arrowheads) suggesting the transfer of the fusion protein into motoneurons from their expression site in the muscle. Bar $=10 \mu \mathrm{m}$. c-g Transneuronal labelling observed 4 days after naked DNA injection: gigantocellular reticular nucleus (c), medial vestibular nucleus (d), control, i.e. gigantocellular reticular nucleus of non-injected animals (e), superior colliculus (f) and motor cortex (g). c-g Bar $=20 \mu \mathrm{m}$.

With regard to the detection of retrograde transport, we found labelling in second-order interneurons, as well as synapsing in higher-order neurons with the hypoglossal motoneurons. In all pCMV- $\beta$-gal-TTC-injected animals, we detected transneuronal labelling in the superior colliculus, gigantocellular reticular nucleus, medial vestibular nucleus and motor cortex (fig. 2). Due to the paucity of $\beta$-galactosidase-labelled axon-like profiles, one cannot exclude that these axons are labelled following a lesion due to the needle used for injection. This could invalidate the existence of a $\beta$-galactosidase transfer from the muscles to the neurons, but not from the first to the second neurons. 
However, no labelled neurons were found in the CNS after Tris-EDTA or pCMV- $\beta$-gal injection. Therefore labelling in neurons is due to the presence of TTC in the fusion protein and not to the transport of plasmids along the axon or to the endogenous $\beta$-galactosidase. Visualization of transsynaptic transport was difficult 30 days after injection, probably due to reduced expression within transfected muscle cells, which is commonly found in many studies using naked DNA.

TTC transport is very specific, as fusion proteins are only found in muscle cells or neurons and not in other cell types. With respect to the possible toxicity caused by TTC encoded from a naked DNA injection, none of the transfected muscles appeared to have been damaged after analyses by optical microscopy. Moreover, no symptoms of tetanus where observed, even when proteins were synthesized by the muscles for 60 days.

\section{Influence of TTC Presence on the Expression Pattern after Naked DNA Administration in the Rat Muscle}

To determine the possible influence of the presence of TTC on the level expression of $\beta$-galactosidase in the muscle, pCMV- $\beta$-gal-TTC, pCMV-NLS- $\beta$-gal or pCMV- $\beta$-gal plasmid constructions were injected into the tongue in both low and high amounts, and the numbers of X-Galpositive myofibres were counted under a dissecting microscope at different postinjection times.

A three-way factorial ANOVA was performed in order to determine the influence of the different plasmid constructions, including the administered dose and postinjection time. There were no significant differences between the number of fibres labelled by the 3 plasmids at different doses or postinjection times $(F=0.008, p>0.05)$. Therefore, the presence of TTC does not modify the evolution time of expression levels. However, we found that the number of labelled fibres depends on both postinjection time and dose $(\mathrm{F}=6.634, \mathrm{p}<0.01$, and $\mathrm{F}=9.087, \mathrm{p}<$ 0.01 , respectively). Also, an interaction between time and dose was detected $(\mathrm{F}=2.450, \mathrm{p}<0.05)$, suggesting that the influence of the dose is not constant over time.

To further quantify the time evolution for the number of labelled fibres, Student's t test was applied (following the result previously described, the plasmid effect was not considered). A statistical analysis was performed separately for each dose, in order to take into account the timedose interaction. According to time evolution of the number of labelled cells, we found that the results could be grouped into three periods consisting of: short term (comprising days 1-4), medium term (days 7-15) and long term (days 30-60). For a given dose, the number of
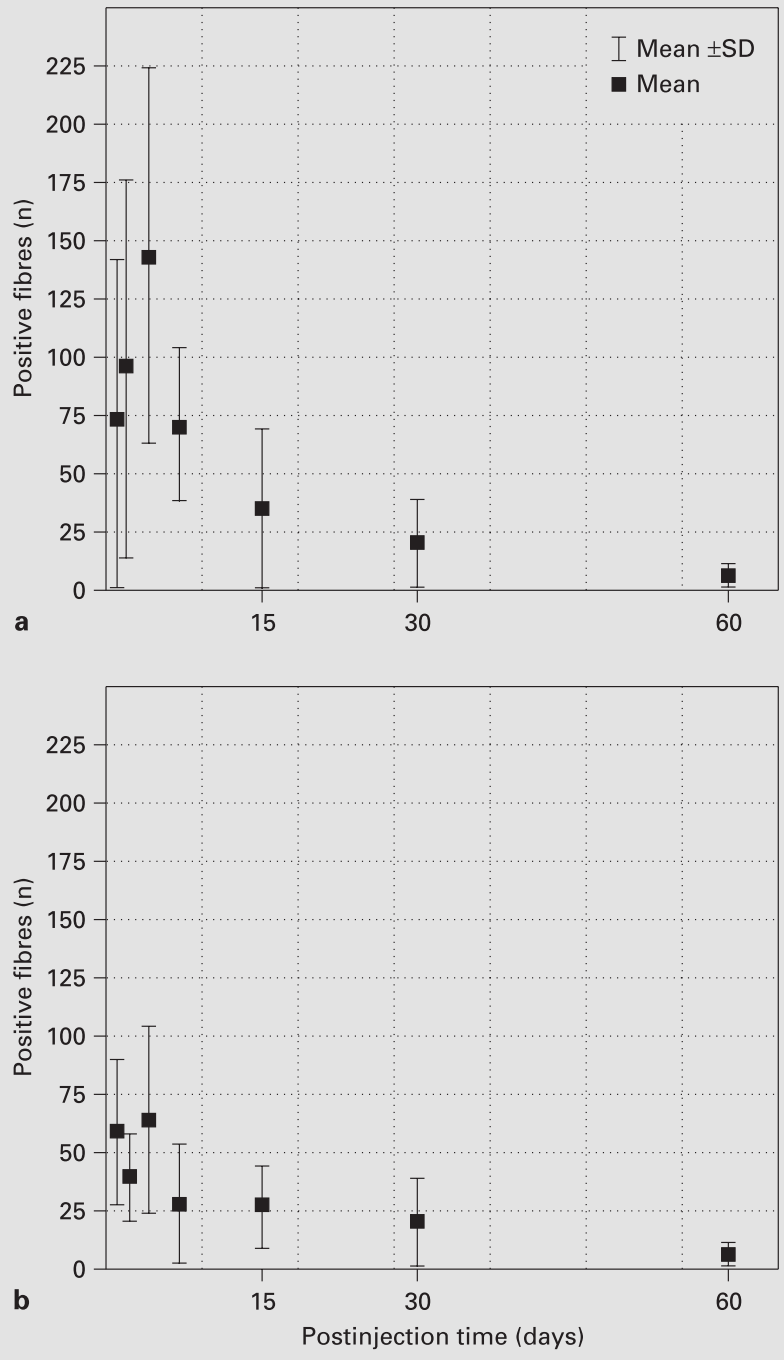

Fig. 3. $p C M V-\beta$-gal-TTC transgene expression in muscle cells. In both the high (a) and low (b) doses, the number of labelled fibres was higher in the short term (first 4 days) and then declined progressively to stabilize until the last observation (60 days). In the short and medium term, the level expression of $\beta$-galactosidase was dose dependent. The variability response was always higher in the short term to decline through time for both doses. However, in the case of the high doses (a), the initial expression level and variability were higher than for low doses (b). In this way, $24 \mathrm{~h}$ after injection, the expression level for high doses was $71.00 \pm 27.96$ and $59.37 \pm 11.86$ positive fibres. Despite this higher variability response to the high doses, positive fibres were always detected. Animals with no positive fibres were detected from day 4 with low administered doses and from day 30 with high injected doses. Mean and variability are only statistically comparable for both doses from day 30 (high dose: 16.00 \pm 7.05 positive fibres; low dose: $20.33 \pm 6.76$ positive fibres). 
labelled cells is different for different periods, but no significant differences were observed within the same period.

With respect to dose dependence, we found that the number of labelled cells is higher for the higher dose in both short and medium terms $(\mathrm{t}=2.43, \mathrm{p}<0.05$, and $\mathrm{t}=$ $2.14, \mathrm{p}<0.05$, respectively) but is dose independent in the long term $(\mathrm{t}=0.38, \mathrm{p}>0.05)$. More precisely, in the short term, the mean number of labelled positive fibres is approximately twice as high for higher doses (100.44 \pm 35.68 fibres) than for lower doses (57.65 \pm 14.54 fibres). However, level expression of $\beta$-galactosidase is not proportional to the administered quantity of DNA, which was 3 times higher for higher doses. High-dose transfection has an effectiveness of 0.33 positive fibres $/ \mu \mathrm{g}$ of injected DNA, approximately 70\% lower than the lowdose one (0.58 fibres/ $\mu$ g DNA). As shown in figure 3 , the level expression of $\beta$-galactosidase difference between doses decreases in the medium term $(28.38 \pm 10.25$ fibres in the low-dose case, $44.31 \pm 24.04$ fibres in the high-dose one) and is not statistically significant in the long term (12.09 \pm 9.91 and $10.66 \pm 8.6$ for low and high doses, respectively).

The variability in responses was higher for high-dose administration than for low doses. In both cases, variability decreases with postinjection time (fig. 3). Similar results have been found in other studies and could be due to individual factors $[20,21]$.

\section{Discussion}

In these studies, we have demonstrated the transport of the muscle-produced $\beta$-gal-TTC protein to the CNS. When fused to TTC, injection of pCMV- $\beta$-gal-TTC into the muscles resulted in localization of the $\beta$-galactosidase protein in the motoneurons of the CNS. Furthermore, when naked DNA was injected into the tongue, the $\beta$-galTTC protein was only found in the hypoglossal network, which corresponds to retrograde and transsynaptic transport of the fusion protein. In this respect, the spatial pattern of the neurons labelled with muscle-produced $\beta$-galTTC is similar to that reported for other conventional tracers, such as the wheat germ agglutinin-horseradish peroxidase complex, neurotrophic viruses such as $\alpha$ herpes [22], rhabdoviruses [23] and the TTC protein when directly injected [11]. With respect to the transport time, we found detectable accumulation of muscle-produced $\beta$-gal-TTC in hypoglossal motoneurons and second-order interneurons within 4 days after injection. This is in contrast with similar studies undertaken in Xenopus where retrograde transport was observed to take at least 30 days after injection [16]. At this time, we cannot provide a complete explanation for this difference; however, a difference in the susceptibility of these animals to tetanus, different muscle activity and/or to different response times to the networks involved may account for the interspecies variability.

At this time, the mechanism by which TTC is secreted from the muscle cell and its uptake by neurons is not known. Although TTC lacks a secretion signal, numerous proteins are known to be secreted by cells while lacking a specific signal [24]. We could hypothesize that the fusion protein synthesized by the transfected muscle is guided and released directly into the synaptic cleft of the neuromuscular junction and then taken up by the motoneuron. TTC internalization into motoneurons has been studied previously, suggesting the role of a dual receptor model: an N-glycosylated $15-\mathrm{kD}$ receptor protein with a neurospecific expression [9] and gangliosides [25]. Both are present in lipid rafts, which are microdomains of the plasma membrane enriched in sphingolipids (including gangliosides), cholesterol and glycosylphosphatidylinositolanchored proteins [26, 27]. These lipid microdomains could be involved in the unconventional muscular secretion mechanism of $\beta$-gal-TTC [28]. The TTC passage across two neurons has already been described $[11,14,15$, 23], but the passage across muscle cells has not previously been reported. This, however, is in accordance with studies showing that TTC enters into muscle cells after a direct intramuscular injection of the protein [25]. Also note that lipid rafts are found in the muscle cells $[29,30]$ and thus could be responsible for the interfibrillary passage observed.

Another important property supporting TTC use in therapy is how it is transported along neurons. TTC fusion protein lacks the translocation domain of native tetanus toxin, which is presumably required for cytosolic entry of tetanus neurotoxin to the cytosol [31]. In this respect, $\beta$-gal-TTC protein injection studies have shown that the protein is never observed to be free in the lumen of vesicles or in the cytosol, its transport always being associated with membranes [32]. In the DNA injection study presented in this paper, the signal detected in the CNS was so weak that electron microscopy analyses of its subcellular location could not be performed. However, we expect the same transport mechanism in the CNS between directly injected and muscle-produced $\beta$-gal-TTC, given that, in both cases, $\beta$-gal-TTC enters the motoneuron already as a protein. The localization of TTC in the

\footnotetext{
$\overline{106} \quad$ Neurodegenerative Dis 2004;1:101-108
} 
membrane could be problematic in some possible therapeutic applications. However, there are substances that act, precisely, at the membrane, as with neurotrophic factors, which act on the receptor in the synaptic cleft membrane and not within the neuronal cytosol. It may be conjectured that the TTC fused to these substances would interact with the receptors in the transsynaptic passage (in the neuromuscular junction or in the central synapses).

With respect to the $\beta$-galactosidase level expression in the muscle cell, the fact that it is not influenced by the presence of TTC indicates that muscle-produced TTC is neither toxic to the muscle cell nor strongly antigenic. This is consistent with the fact that polypeptide or toxoid vaccines generated a higher response than DNA when fragment $\mathrm{C}$ was used on its own to control tetanus disease [33].

The evolution time of $\beta$-galactosidase level expression reported in this paper is in accordance with previous studies of shaving expression after $\beta$-galactosidase naked DNA injection into leg and arm muscles [20]. The origin of the temporal decrease in expression is not totally clear; it could be due to the Th1 (cytotoxic) immune response or to the presence of endogenous endonucleases, as previously postulated [20,34]. In comparison to previous studies, we found that the number of labelled fibres is smaller for injections into the tongue muscle. This is not surprising, as muscle characteristics such as its connective tissue, spatial configuration and/or different fibre type distributions could be involved in expression levels [33].

The smaller transfection effectiveness obtained for high doses may be related to the reported decrease in transfection level when the injected volume increases [20]. In our study, the injected volume in the high-dose case was 3 times larger than in the low-dose case. In spite of this lower effectiveness of the high dose, we have only observed lack of expression before 30 days in low-doseinjected animals. Hence, a high amount of injected DNA guarantees protein expression (although most of the DNA was degraded [21]), which could be important for gene therapy. It would be desirable to improve the transfer effectiveness and to decrease the variability; different strategies considered are electroporation and the combination of TTC with viral vectors $[35,36]$. However, for some uses, a more effective transfer might not be strictly necessary: for instance, neurotrophic factors have been effective for motoneural survival at very low concentrations (from $40 \mathrm{pg} / \mathrm{ml}$ to $0.1 \mathrm{ng} / \mathrm{ml}$ ) [37-39].

To summarize, direct injection of a single dose of $\beta$ gal-TTC plasmid DNA into rat tongue muscle results in the uptake of encoded $\beta$-gal-TTC protein by the hypoglossal motoneurons and their connections. $\beta$-gal-TTC proteins are already found in the CNS 4 days after injection, and their presence is detectable for at least 60 days. Additionally, we have shown that the presence of TTC does not have any influence on the expression of the transfected gene. The presence of TTC in the CNS and the lack of nervous (or other) symptoms, even 60 days after injection, strongly suggests that muscle-produced $\beta$-gal-TTC is not toxic to the animal. Based on these results, we propose a gene therapy approach based on different TTC fusion proteins, which could help deliver a biological function to the CNS. We believe that this is an interesting method as a therapeutic strategy for degenerative motoneuron diseases, and further studies are therefore warranted to investigate the potential of these fusion proteins to use in protocols of human gene therapy.

\section{Acknowledgements}

We wish to thank Mamen Morillo and José Ignacio Rivera for their technical support, also Luis Martin Moreno and Kelly Rogers for their suggestions and finally Gema Yagüe for her help with the statistical analyses. This work was supported by a grant from the Fondo de Investigacion Sanitaria (PI020840) and Red CIEN.

\section{References}

$>1$ Lin LF, Zhang TJ, Collins F, Armes LG: Purification and initial characterization of rat B49 glial cell line-derived neurotrophic factor. J Neurochem 1994;63:758-768.

$\checkmark 2$ Miller RG, Petajan JH, Bryan WW, Armon C, Barohn RJ, Goodpasture JC, Hoagland RJ, Parry GJ, Ross MA, Stromatt SC: A placebocontrolled trial of recombinant human ciliary neurotrophic (rhCNTF) factor in amyotrophic lateral sclerosis. rhCNTF ALS Study Group. Ann Neurol 1996;39:256-260.
3 Acsadi G, Anguelov RA, Yang H, Toth G, Thomas R, Jani A, Wang Y, Ianakova E, Mohammad S, Lewis RA, Shy ME: Increased survival and function of SOD1 mice after glial cellderived neurotrophic factor gene therapy. Hum Gene Ther 2002;13:1047-1059.

4 Millecamps S, Mallet J, Barkats M: Adenoviral retrograde gene transfer in motoneurons is greatly enhanced by prior intramuscular inoculation with botulinum toxin. Hum Gene Ther 2002;13:225-232. Lu YY, Wang LJ, Muramatsu S, Ikeguchi K, Fujimoto K, Okada T, Mizukami H, Matsushita T, Hanazono Y, Kume A, Nagatsu T, Ozawa K, Nakano I: Intramuscular injection of AAVGDNF results in sustained expression of transgenic GDNF, and its delivery to spinal motoneurons by retrograde transport. Neurosci Res 2003;45:33-40. 
6 Cisterni C, Henderson CE, Aebischer P, Pettmann B, Deglon N: Efficient gene transfer and expression of biologically active glial cell linederived neurotrophic factor in rat motoneurons transduced wit lentiviral vectors. J Neurochem 2000;74:1820-1828.

7 Halpern JL, Habig WH, Neale EA, Stibitz S Cloning and expression of functional fragment C of tetanus toxin. Infect Immun 1990;58: 1004-1009.

$>8$ Goldberg RL, Costa T, Habig WH, Kohn LD, Hardegree MC: Characterization of fragment C and tetanus toxin binding to rat brain membranes. Mol Pharmacol 1981;20:565-570.

$\checkmark 9$ Herreros J, Lalli G, Montecucco C, Schiavo G: Tetanus toxin fragment $\mathrm{C}$ binds to a protein present in neuronal cell lines and motoneurons. J Neurochem 2000;74:1941-1950.

10 Fishman PS, Savitt JM: Transsynaptic transfer of retrogradely transported tetanus proteinperoxidase conjugates. Exp Neurol 1989;106: 197-203.

-11 Coen L, Osta R, Maury M, Brulet P: Construction of hybrid proteins that migrate retrogradely and transynaptically into the central nervous system. Proc Natl Acad Sci USA 1997; 94:9400-9405.

12 Matthews CC, et al: Protective effect of supplemental superoxide dismutase on survival of neuronal cells during starvation: Requirement for cytosolic distribution. J Mol Neurosci 2000; 14:155-166.

13 Figueiredo DM, et al: Delivery of recombinant tetanus-superoxide dismutase proteins to central nervous system neurons by retrograde axonal transport. Exp Neurol 1997;145:546-554.

-14 Francis JW, Hosler BA, Brown RH Jr, Fishman PS: CuZn superoxide dismutase (SOD-1): Tetanus toxin fragment $\mathrm{C}$ hybrid protein for targeted delivery of SOD-1 to neuronal cells. J Biol Chem 1995;270:15434-15442.

$\checkmark 15$ Bordet T, Castelnau-Ptakhine L, Fauchereau F, Friocourt G, Kahn A, Haase G: Neuronal targeting of cardiotrophin-1 by coupling with tetanus toxin $\mathrm{C}$ fragment. Mol Cell Neurosci 2001;17:842-854.

16 Coen L, Kissa K, le Mevel S, Brulet P, Demeneix BA: A somatic gene transfer approach using recombinant fusion proteins to map muscle-motoneuron projections in Xenopus spinal cord. Int J Dev Biol 1999;43:823-830.
17 Rosenberg WS, Breakefield XO, DeAntonio C, Isacson O: Authentic and artifactual detection of the E. coli lacZ gene product in the rat brain by histochemical methods. Brain Res Mol Brain Res 1992;16:311-315.

18 Weiss DJ, Liggitt D, Clark JG: Histochemical discrimination of endogenous mammalian beta-galactosidase activity from that resulting from lac-Z gene expression. Histochem J 1999; 31:231-236.

19 Bonnerot C, Rocancourt D, Briand P, Grimber G, Nicolas JF: A beta-galactosidase hybrid protein targeted to nuclei as a marker for developmental studies. Proc Natl Acad Sci USA 1987; 84:6795-6799.

20 Doh SG, Vahlsing HL, Hartikka J, Liang X, Manthorpe M: Spatial-temporal patterns of gene expression in mouse skeletal muscle after injection of lacZ plasmid DNA. Gene Ther 1997;4:648-663.

21 Barry ME, Pinto-Gonzalez D, Orson FM, McKenzie GJ, Petry GR, Barry MA: Role of endogenous endonucleases and tissue site in transfection and CpG-mediated immune activation after naked DNA injection. Hum Gene Ther 1999; 10:2461-2480.

22 Ugolini G: Transneuronal tracing with alphaherpesviruses: A review of the methodology; in Kaplitt MG, Loewy AD (eds): Viral Vectors. Gene Therapy and Neuroscience Applications. New York, Academic Press, 1995, pp 293317.

23 Ugolini G: Specificity of rabies virus as a transneuronal tracer of motor networks: Transfer from hypoglossal motoneurons to connected second-order and higher order central nervous system cell groups. J Comp Neurol 1995;356: 457-480.

24 Prochiantz A: Homeodomain-derived peptides: In and out of the cells. Ann NY Acad Sci 1999;886:172-179.

25 Herreros J, Ng T, Schiavo G: Lipid rafts act as specialized domains for tetanus toxin binding and internalization into neurons. Mol Biol Cell 2001;12:2947-2960

26 Simons K, Gruenberg J: Jamming the endosomal system: Lipid rafts and lysosomal storage diseases. Trends Cell Biol 2000;10:459-462.
27 Brown DA, London E: Structure, and function of sphingolipid-, and cholesterol-rich membrane rafts. J Biol Chem 2000;275:1722117224.

28 Simons K, Ikonen E: Functional rafts in cell membranes. Nature 1997;387:569-572.

29 Galbiati F, Razani B, Lisanti MP: Emerging themes in lipid rafts and caveolae. Cell 2001; 106:403-411.

30 Kurzchalia TV, Parton RG: Membrane microdomains and caveolae. Curr Opin Cell Biol 1999;11:424-431.

31 Montecucco C, Schiavo G, Rossetto O: The mechanism of action of tetanus and botulinum neurotoxins. Arch Toxicol Suppl 1996;18:342354.

32 Miana-Mena FJ, Roux S, Benichou JC, Osta R, Brulet P: Neuronal activity-dependent membrane traffic at the neuromuscular junction. Proc Natl Acad Sci USA 2002;99:3234-3239.

33 Zhang G, Budker V, Williams P, Subbotin V, Wolff JA: Efficient expression of naked DNA delivered intra-arterially to limb muscles of nonhuman primates. Hum Gene Ther 2001; 12:427-438.

34 Wells KE, et al: Immune responses, not promoter inactivation, are responsible for decreased long-term expression following plasmid gene transfer into skeletal muscle. FEBS Lett 1997;407:164-168.

35 Mir LM, et al: High-efficiency gene transfer into skeletal muscle mediated by electric pulses. Proc Natl Acad Sci USA 1999;96:42624267.

36 Mathiesen I: Electropermeabilization of skeletal muscle enhances gene transfer in vivo. Gene Ther 1999;6:508-514.

37 Oppenheim RW, et al: Developing motor neurons rescued from programmed and axotomyinduced cell death by GDNF. Nature 1995; 373:344-346.

38 Oppenheim RW, Prevette D, Yin QW, Collins F, MacDonald J: Control of embryonic motoneuron survival in vivo by ciliary neurotrophic factor. Science 1991;251:1616-1618.

39 Ma YT, Hsieh T, Forbes ME, Johnson JE, Frost DO: BDNF injected into the superior colliculus reduces developmental retinal ganglion cell death. J Neurosci 1998;18:2097-2107. 